University of Nebraska - Lincoln

DigitalCommons@University of Nebraska - Lincoln

USDA Wildlife Services - Staff Publications

U.S. Department of Agriculture: Animal and Plant Health Inspection Service

2012

\title{
Movement and Habitat Use of Feral Swine Near Domestic Swine Facilities
}

A. Christy Wyckoff

Texas A \& M University - Kingsville, cwyckoff@slconservancy.org

Scott E. Henke

Texas A \& M University - Kingsville, scott.henke@tamuk.edu

Tyler A. Campbell

USDA/APHIS/WS/NWRC, tcampbell@eastfoundation.net

David G. Hewitt

Texas A \& M University - Kingsville, david.hewitt@tamuk.edu

Kurt C. VerCauteren

USDA-APHIS-Wildlife Services, kurt.c.vercauteren@usda.gov

Follow this and additional works at: https://digitalcommons.unl.edu/icwdm_usdanwrc

Part of the Life Sciences Commons

Wyckoff, A. Christy; Henke, Scott E.; Campbell, Tyler A.; Hewitt, David G.; and VerCauteren, Kurt C., "Movement and Habitat Use of Feral Swine Near Domestic Swine Facilities" (2012). USDA Wildlife Services - Staff Publications. 1087.

https://digitalcommons.unl.edu/icwdm_usdanwrc/1087

This Article is brought to you for free and open access by the U.S. Department of Agriculture: Animal and Plant Health Inspection Service at DigitalCommons@University of Nebraska - Lincoln. It has been accepted for inclusion in USDA Wildlife Services - Staff Publications by an authorized administrator of DigitalCommons@University of Nebraska - Lincoln. 


\title{
Movement and Habitat Use of Feral Swine Near Domestic Swine Facilities
}

\author{
A. CHRISTY WYCKOFF, Caesar Kleberg Wildlife Research Institute, Texas AछM University-Kingsville, Kingsville, TX 78363, USA \\ SCOTT E. HENKE, ${ }^{1}$ Caesar Kleberg Wildife Research Institute, Texas AङM University-Kingsville, Kingsville, TX 78363, USA \\ TYLER A. CAMPBELL, ${ }^{2}$ United States Department of Agriculture, Animal and Plant Health Inspection Service, Wildife Services, \\ National Wildife Research Center, Texas AEM University-Kingsville, Kingsville, TX 78363, USA \\ DAVID G. HEWITT, Caesar Kleberg Wildlife Research Institute, Texas AङM University-Kingsville, Kingsville, TX 78363, USA \\ KURT C. VerCAUTEREN, United States Department of Agriculture, Animal and Plant Health Inspection Service, Wildlife Services, \\ National Wildife Research Center, Fort Collins, CO 80521, USA
}

\begin{abstract}
Feral swine (Sus scrofa), a successful invasive species in the United States, have established growing populations in 38 states and are a reservoir of diseases important to domestic swine. An understanding of habitat use and movements is important for the prevention of disease transmission between feral and domestic swine. To assess risk posed to neighboring domestic swine facilities in East and South Texas, we determined habitat use and movement patterns of feral swine within 10 miles of domestic swine facilities, identified similarities in habitat preferences and vegetation types directly surrounding facilities, assessed effects of wet and dry conditions on general habitat use, and determined whether landscape features such as corridors or boundaries influenced movements across utilized habitats. Kernel area values (95\% isopleths) for wet and dry periods were different $\left(F_{2,16}=6.38, P=0.005\right)$ between East and South Texas. Feral swine preferred habitat characteristics commonly found surrounding domestic swine facilities. Feral swine also demonstrated disproportionate use of specific vegetation types as compared to availability during both wet and dry periods. Additionally, the presence of paved, 2-lane roads influenced movements of feral swine. The new knowledge of habitat use and landscape movements we present can be used for more efficient application of targeted management and eradication strategies near domestic swine facilities, particularly in emergency situations such as disease outbreaks. Published 2012. This article is a U.S. Government work and is in the public domain in the USA.
\end{abstract}

KEY WORDS contact, disease, domestic swine, feral swine, GPS collar, habitat use, Sus scrofa, Texas.

Feral swine (Sus scrofa) are opportunistic omnivores and have established populations in a myriad of habitat types across the United States (Fogarty 2007, Southeastern Cooperative Wildlife Disease Study [SCWDS] 2008). Over the last 30 years, feral swine populations have expanded their distribution throughout the state of Texas, USA into seemingly suboptimal habitats such as the arid deserts and high plains of western Texas (Adkins and Harveson 2007, SCWDS 2008). Factors cited for this expansion include high reproductive rates (Taylor et al. 1998), changes in land use, development of agriculture and irrigation in arid climates (Taylor 1993), eradication of screwworm for livestock health (Taylor 1993), and increased illegal relocation of feral swine into new regions for sport hunting (Gipson et al. 1998, Delgado-Acevedo 2010).

A major concern with feral swine is their potential to maintain and transmit economically significant diseases to domestic swine (Witmer et al. 2003, Wyckoff et al. 2009).

Received: 22 December 2010; Accepted: 26 October 2011; Published: 10 February 2012

\footnotetext{
${ }^{1}$ E-mail: scott.henke@tamuk.edu

${ }^{2}$ Present address: USDA/APHIS/WS/NWRC, Florida Field Station, 2820 East University Avenue, Gainesville, FL 32641, USA.
}

They have been implicated in 3 outbreaks of swine brucellosis in domestic herds (Feral Swine Subcommittee on Brucellosis and Pseudorabies 2005), and also play an important role in human health pathogens such as Escherichia coli O157:H7 (Jay et al. 2007). The domestic swine industry is dominated by operations with some level of biosecurity (Witmer et al. 2003). However, a portion of the industry is considered 'backyard' or transitional production, hereafter referred to as small-scale facilities, consisting of show pigs, breeders, and small-scale meat producers (Doster 1992). It is these smaller operations that provide opportunity for disease transmission between feral and domestic swine through fence lines and fomites (Wyckoff et al. 2009). For disease management planning and implementation, data regarding feral swine movements, habitat preference, and the influence of boundaries and corridors near these small-scale production facilities are needed but lacking (Auld and Tisdell 1986, Wyckoff et al. 2009). These data could be useful for targeting depopulation or habitat manipulation efforts toward preferred habitats and travel corridors. It has also been suggested that roads, rivers, and railways may present boundaries to feral swine movement; thus, boundaries may be used to inhibit feral swine from entering an area or crossing into new regions (Saunders and Kay 1991). If a population must 
be eradicated quickly due to a disease outbreak, information on how feral swine use the landscape can help identify the scope of the population of concern and likely habitat types to target, allowing for expedited eradication (Saunders and Bryant 1988).

Studies of habitat use and movements of feral swine suggest that feral swine prefer riparian areas and swampy bottomlands that provide dense vegetation for cover, water for thermoregulation, and lush vegetation and high mast production for forage (Synatzske 1979, Ilse and Hellgren 1995, Dexter 1998, Mersinger and Silvy 2007). Thus, movement of feral swine will be influenced by seasonal food availability, shelter, and water distribution (Hayes et al. 2009). Additional influences on movement could include hunting pressure (Saunders and Kay 1991), riparian corridors, cleared pipeline or power line right-of-ways, and potential physical boundaries such as roads or rivers (Saunders and Kay 1991, Forman 1995). These habitat use preferences should be considered when assessing disease transmission risk to transitional domestic swine facilities.

Our goal was to evaluate feral swine movements and habitat use near small-scale facilities. Specific objectives were to 1) identify similarities in feral swine habitat preference and habitat surrounding domestic swine facilities, 2) determine whether corridors and boundaries affect feral swine movements, 3) calculate areas of utilization and identify patterns of habitat use, and 4) determine whether dry and wet periods affect seasonal habitat use by feral swine in Texas. Additionally, we suggest management strategies to prevent disease transmission from feral to domestic swine at smallscale facilities.

\section{STUDY AREA}

We conducted our study in 3 Texas ecotypes, South Texas Plains, Pineywoods, and the Post Oak Savanna (Gould 1975; Fig. 1). In each ecotype, we chose trapping locations $\leq 10 \mathrm{~km}$ from domestic swine facilities. Swine facilities targeted in this study were classified as small-scale, low-biosecurity outdoor pens, with fence lines available to feral-domestic swine contact. These facilities varied from small show-pig operations consisting of 2-10 animals, to larger pork-production facilities of 100 animals. Study sites located within the South Texas Plains (Gould 1975) were comprised of private ranch lands, Texas A\&M University La Copita Research Area (N 27 $46^{\prime}$, W $98^{\circ} 09^{\prime}$ ), and Texas A\&M UniversityKingsville farm facilities (N 27 $34^{\prime}$, W 97 $50^{\prime}$ ). Habitat consisted primarily of agricultural fields (sorghum and cotton), open range, and mesquite (Prosopis glandulosa)-predominated shrubland. Annual precipitation was $87 \mathrm{~cm}$ in 2004, $54 \mathrm{~cm}$ in 2005, and $40 \mathrm{~cm}$ through August of 2006, with a historical average of $70 \mathrm{~cm}$ (NOAA 2006). Study sites located in the Post Oak (Quercus stellata) Savannah included the Gus Engeling Wildlife Management Area (WMA; 4,434 ha; N 31 $56^{\prime}$, W 95 53'; Texas Parks and Wildlife) and the Big Lake Bottom WMA (3,076 ha; N 31 $44^{\prime}$, W 95 48'; Texas Parks and Wildlife). Habitat consisted of mixed hardwoods and bottomland swamps (Gould 1975). Annual rainfall was $144 \mathrm{~cm}$ in $2004,71 \mathrm{~cm}$ in

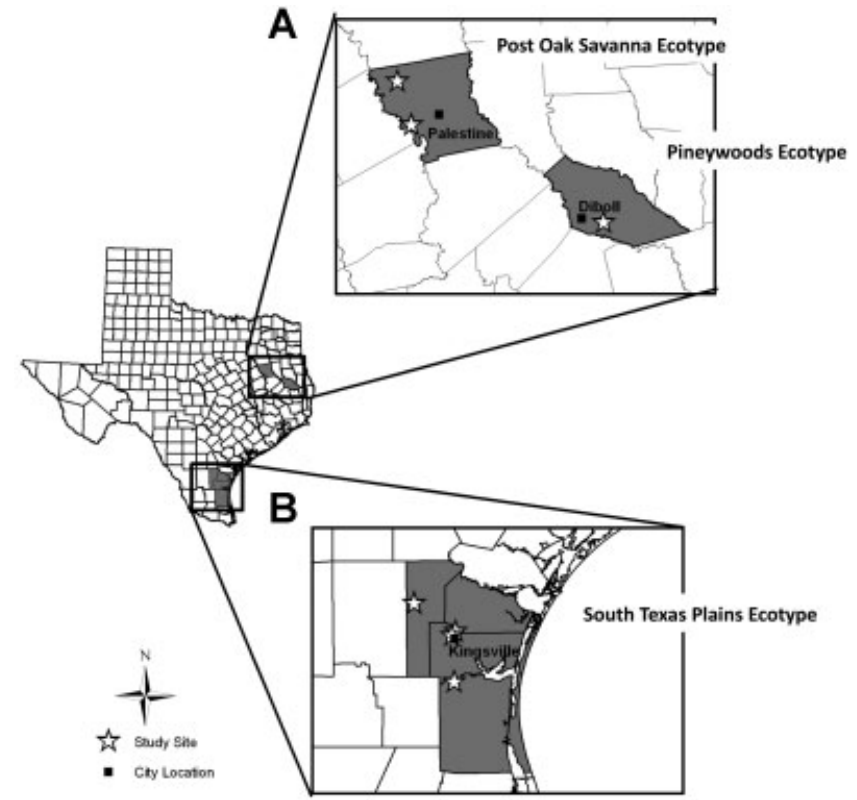

Figure 1. Study regions where feral swine were fitted with Global Positioning System collars for data collection on movements and habitat use in (A) Pineywoods and Post Oak Savanna, and (B) South Texas Plains, Texas, USA, at sites $\leq 10 \mathrm{~km}$ from domestic swine facilities, May 2004-July 2006.

2005, and $65 \mathrm{~cm}$ through August of 2006, with historical averages of $100 \mathrm{~cm}$ (NOAA 2006). Finally, the study sites located in the Pineywoods (Gould 1975) were all contained within an industrial timberland operation ( $\mathrm{N} \mathrm{31} 1^{\circ} 10^{\prime}, \mathrm{W}$ $94^{\circ} 43^{\prime}$ ). Habitat consisted of loblolly pine (Pinus taeda) plantations, hardwoods mixed with palmetto (Sable spp.) flats, a river basin, and associated bottomland swamps. Annual rainfall was $198 \mathrm{~cm}$ in 2004, $80 \mathrm{~cm}$ in 2005, and $60 \mathrm{~cm}$ through August of 2006, with historical averages of $100 \mathrm{~cm}$ (NOAA 2006).

\section{METHODS}

We used box and corral traps to capture small groups of feral swine. We immobilized trapped feral swine with $3-\mathrm{cm}^{3}$ darts containing Telazol and xylazine delivered by an air-pump projector (Pneu-Dart, Inc., Williamsport, PA) with dosages calculated according to Wyckoff et al. (2009). We monitored heart rate, respiration rate, and temperature of feral swine while immobilized. We administered cool-water enemas to heat-stressed, immobilized animals, to lower body temperatures. We recorded weights and sex, and ear-tagged all trapped animals with an individual identification number and our contact information. All captured adults with a neck circumference $\geq 62.5 \mathrm{~cm}$ were fitted with Global Positioning System (GPS) collars (Televilt Co., Sweden). We followed approved handling procedures of Texas A\&M University-Kingsville Animal Care and Use Committee (IACUC permit 1-04-36), and the Institutional Animal Care and Use Committee of the National Wildlife Research Center (QA-1240).

We programmed collars to $\log$ and store satellite-acquired locations every 4 hours, 4 days/week (i.e., 24 locations/week) 
for 2.1 years (May 2004 to Jul 2007). Once per month during the programmed very high frequency period, we used fixedwing aircraft to locate collared feral swine to determine whether the animals were still alive and the general location of each collared animal. We recovered collars from hunterharvested feral swine, feral swine that died, or collars that slipped off animals. Habitat and canopy cover did not influence efficacy of data collection (unpulished data).

We used rainfall, and resulting vegetation growth, to assess environmental influence on feral swine movements in a post hoc analysis due to climactic extremes over the 2 years of the study. Additionally, feral swine do not have well-defined breeding seasons (Taylor 1993). Therefore, we used the Palmer Drought Severity Index (PDSI; Palmer 1965) to delineate wet, normal, and dry periods for South Texas Plains sites (South Central Climate Division), and Post Oak Savanna and Pineywood sites (East Texas Climate Division). Weekly PDSI values were obtained from the National Climate Prediction Center of the NOAA (2006) and graphed (Fig. 2). In South Texas Plains sites, the wet, normal, and dry periods were from 1 May 2004 to 4 June 2005, 4 June 2005 to 7 January 2006, and 7 January 2006 to 1 July 2006, respectively. Post Oak Savanna and Pineywood sites were less clearly delineated; however, the general trend was a wet period from 1 May 2004 to 28 May 2005, and a dry period from 28 May 2005 to 1 July 2006.

We analyzed location data with ArcView 9.1. Data were overlaid onto Landsat images (Digital Orthophoto Quarter Quadrangle) for habitat utilization analysis. To determine the minimum number of data collection days required for representative habitat use, and the minimum number of locations required in the time frame, we calculated fixedkernel area values by 10 -day increments. The first 10 days of data collection were assessed and compared to a random sampling of 10-day periods within the data collection period. We used these values to assess area curves for feral swine over time and found minimal slope on the area curves (unpulished

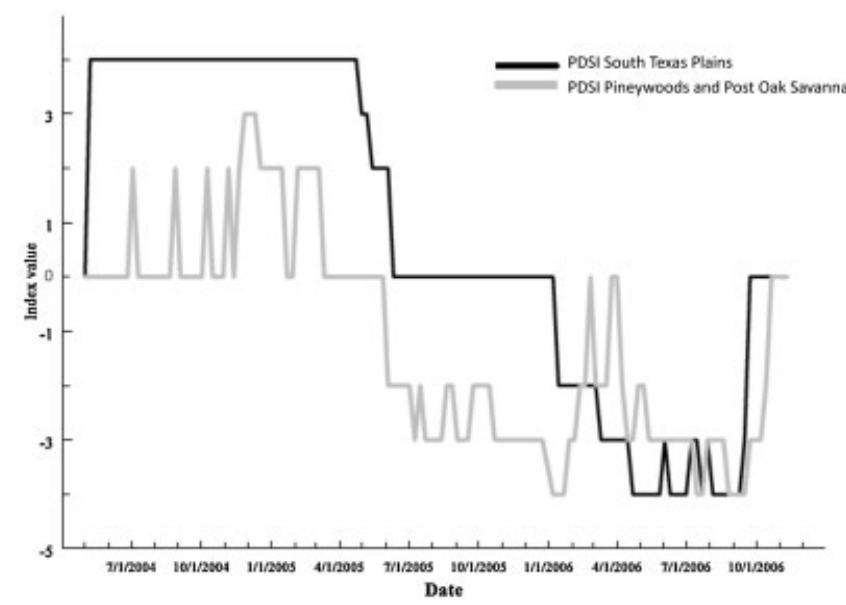

Figure 2. Palmer Drought Severity Index (PDSI) weekly trends in South Texas Plains, Pineywoods, and the Post Oak Savanna, Texas, USA ecotypes during GPS collar data collection, May 2004-July 2006. Values above $0=$ wet, at $0=$ normal, and below $0=$ dry. data) indicating area measures were not altered with increased sample size. Therefore, collars with $>10$ days of data collected, and $>30$ locations, were included in the analysis (Kenward 2001). Keeping collars on feral swine is difficult due to swine neck morphology, hunting pressures, and a 51\% rate of collar failure (Wyckoff et al. 2007), resulting in much variation in monitoring duration, collection of location data, and sex ratios of collared swine at each study site (Wood and Brenneman 1980, Massei et al. 1997). Thus, we used the term "area of utilization" instead of "home range" (Bailey 1984) to avoid suggesting this is the full extent of habitat used. Areas of utilized habitat were calculated for each animal during the wet, normal (only South Texas Plains sites), and dry periods using the $95 \%$ kernel operation of the Home Range Extension for ArcView (Rodgers and Carr 1998).

We used an unbalanced factorial analysis of variance to assess utilization with sites, sex, and periods (wet, normal and dry) as main effects (Atwood et al. 2007). Least-squares means were calculated for mean separation, and significance was set at $P=0.05$. South Texas Plains had 3 PDSI periods for which we also used a separate unbalanced factorial analysis of variance to assess variation between sexes and PDSI periods (Littell et al. 2006).

To determine available habitat for each ecotype site, we combined location data sets of all the animals at each site, and created a $100 \%$ fixed kernel that included all pooled locations and then generated an approximately $4-\mathrm{km}$ buffer. We used $4-\mathrm{km}$ buffer because it was half the average length of the longest kernel-axis estimate of utilized areas of collared feral swine in our study.

We used the Texas Gap Analysis Program (TX-GAP) classified land cover image to identify vegetation classifications, hereto referred to as vegetation types (Hall et al. 1997), at each of our study sites (U.S. Geological Survey GAP Analysis Project 2003, Moen et al. 2008). The TX-GAP data are comprised of 30-m pixels generalized to one dominant vegetation type. Vegetation classifications were based off of spectral data collected by satellite, with corresponding ground observations of vegetation classes in each Texas ecotype (U.S. Geological Survey GAP Analysis Project 2003). South Texas sites were categorized as South Texas Plains, our 2 eastern sites were Post Oak Savanna and Pineywoods, respectively (see Table 1 for GAP classifications and our summarized habitat classifications). We classified predominant vegetation types surrounding each domestic facility with regard to feral swine habitat preference.

To assess habitat use, we created a resource selection function model (Manly et al. 2002) to determine whether preferences for available vegetation types occurred (Boyce et al. 2002). To quantify available vegetation types we generated an equal number (to the pooled no. of known animal locations) of random locations across each classified image. These randomly generated locations were bounded within the utilized area of feral swine in each of the 3 ecotypes, as defined above. We used ArcView 9.1 to assign each location a vegetation classification according to the TX-GAP GPS layer. Each location scored a 1 for the type of vegetation it 
Table 1. Modified GAP habitat classifications by region with estimate coefficient, standard error (SE), and Wald chi-squared statistic, for proportion of habitat use by feral hogs with respect to availability in 3 Texas, USA, ecotypes, May 2004-July 2006.

\begin{tabular}{|c|c|c|c|c|c|c|c|c|c|}
\hline \multirow{2}{*}{$\begin{array}{l}\text { Study area ecotype } \\
\text { Habitat classification }\end{array}$} & \multicolumn{3}{|c|}{ Wet period $^{\mathrm{a}}$} & \multicolumn{3}{|c|}{ Normal period $^{\mathrm{a}}$} & \multicolumn{3}{|c|}{ Dry period $^{a}$} \\
\hline & Estimate & SE & Wald & Estimate & SE & Wald & Estimate & SE & Wald \\
\hline \multicolumn{10}{|l|}{ South Texas Plains } \\
\hline Water & $\mathrm{p}^{\mathrm{b}}$ & na & na & $\mathrm{p}$ & na & na & $\mathrm{p}$ & na & na \\
\hline Bare ground & 0.71 & 0.19 & 13.35 & $\mathrm{p}$ & $\mathrm{p}$ & $\mathrm{p}$ & $\mathrm{p}$ & na & na \\
\hline Cropland & -0.38 & 0.07 & 28.62 & $\mathrm{p}$ & $\mathrm{p}$ & $\mathrm{p}$ & $\mathrm{p}$ & na & na \\
\hline Urban & -3.76 & 0.72 & 27.42 & -15.42 & 312.5 & 0.002 & $\mathrm{p}$ & na & na \\
\hline Mesquite shrubland ${ }^{c}$ & $\mathrm{p}$ & na & na & $\mathrm{p}$ & na & na & $\mathrm{p}$ & na & na \\
\hline Riparian woodlands ${ }^{\mathrm{d}}$ & $\mathrm{p}$ & na & na & $\mathrm{p}$ & na & na & $\mathrm{p}$ & na & na \\
\hline Grasslands ${ }^{\mathrm{e}}$ & -1.72 & 0.19 & 84.89 & -1.9 & 0.2 & 90.17 & $\mathrm{p}$ & na & na \\
\hline Mesquite/oaks woodlands ${ }^{\mathrm{f}}$ & -0.58 & 0.11 & 30.3 & -1.1 & 0.18 & 38.61 & $\mathrm{p}$ & na & na \\
\hline \multicolumn{10}{|l|}{ Post Oak Savanna } \\
\hline Cropland & -0.35 & 0.13 & 7.69 & & & & -0.95 & 0.18 & 27.74 \\
\hline Pine forest ${ }^{g}$ & $\mathrm{p}$ & na & na & & & & $\mathrm{p}$ & na & na \\
\hline Oak shrubland $^{\mathrm{h}}$ & $\mathrm{p}$ & na & na & & & & -0.93 & 0.35 & 7.07 \\
\hline Riparian woodlands & $\mathrm{p}$ & na & na & & & & $\mathrm{p}$ & na & na \\
\hline Grasslands & 1.12 & 0.57 & 3.86 & & & & $\mathrm{p}$ & na & na \\
\hline Mesquite-oak woodlands & $\mathrm{p}$ & na & na & & & & $\mathrm{p}$ & na & na \\
\hline Mixed oak woodlands ${ }^{\mathrm{i}}$ & -0.47 & 0.15 & 9.39 & & & & p & na & na \\
\hline Live oak woodlands ${ }^{j}$ & $\mathrm{p}$ & na & na & & & & $\mathrm{p}$ & na & na \\
\hline \multicolumn{10}{|l|}{ Pineywoods } \\
\hline Water & $\mathrm{p}$ & na & na & & & & $\mathrm{p}$ & na & na \\
\hline Cropland & -13.38 & 329.2 & 0.0017 & & & & $\mathrm{p}$ & na & na \\
\hline Urban & $\mathrm{p}$ & na & na & & & & $\mathrm{p}$ & na & na \\
\hline Pine forest & $\mathrm{p}$ & na & na & & & & 38.29 & 1.02 & 12.73 \\
\hline Riparian woodlands & -0.84 & 0.32 & 6.78 & & & & $\mathrm{p}$ & na & na \\
\hline Grasslands & -2.05 & 0.24 & 75.35 & & & & $\mathrm{p}$ & na & na \\
\hline Water oak woodlands ${ }^{\mathrm{k}}$ & 0.57 & 0.29 & 3.77 & & & & 16.69 & 1.12 & 6.33 \\
\hline
\end{tabular}

${ }^{a}$ Palmer Drought Severity Index (PDSI)-delineated periods.

${ }^{\mathrm{b}}$ Indicates proportional use-to-availability point estimate of 1 ; these variables fell out of final model due to lack of significance. No SE or Wald values are reported.

${ }^{\mathrm{c}}$ Extremely xeromorphic deciduous shrubland.

d Temporarily flooded cold-deciduous woodland.

e Short-sod temperate grassland.

${ }^{\mathrm{f}}$ Cold-deciduous woodland.

${ }^{\mathrm{g}}$ Rounded-crowned temperate needle-leaved evergreen forest.

${ }^{\mathrm{h}}$ Lowland mixed evergreen-drought-deciduous shrubland.

${ }^{i}$ Round-crowned temperate needle-leaved evergreen woodland.

${ }^{\mathrm{j}}$ Temperate broad-leaved evergreen woodland.

${ }^{\mathrm{k}}$ Lowland cold-deciduous forest.

was located in (present) and a 0 for all other types of vegetation of the respective ecotype (available) to form a matrix (Atwood et al. 2007). We repeated this process with locations collected by GPS collars on feral swine. The binomial projection of presence verses available was then run in a logistic regression model. Model output of point estimates for proportional use scaled from $<1$ (demonstrating underuse), 1 (proportional use), and $>1$ (showing an overuse compared to proportional availability). We used the Deviance and the Pearson's chi-squared goodness-of-fit tests to check models (Mladenoff et al. 1995).

To determine whether oil pipeline and power line right-ofways function as feral swine movement corridors, in a post hoc analysis, we generated a $98 \%$ kernel using all the locations in each of the 3 sites and delineated the right-of-ways as polygons. We used $98 \%$ to achieve a conservative continuity of the included habitat, but not over estimate included habitat by using the $100 \%$ kernel. We then computed the density of locations that fell within the pipeline and power line right-of-ways for each site. By using randomly generated polygons of similar length, width, and area within the $98 \%$ kernel contour, we computed the density of locations that fell within these random polygons. We tested each ecotype using the Wilcoxon Signed-Rank Test.

We used the location data from GPS-equipped feral swine to make a simple post hoc assessment of the permeability of paved, 2-lane, and maintained caliche dirt roads. We used the average kernel axis length of the areas of utilization at each ecotype site, to create a buffer around each road type to identify which feral swine would have potentially encountered the road in their movements. If an individual kernel did not overlap with the road buffer, that animal was not included in the analysis for that type of road. We used the path function of Animal Movements in Hawths Analysis Tools Extension (for ArcView: Hawthorne Beyer, version 3.01) to assess each crossing event for each road included in the site. We identified habitat types of precrossing and postcrossing locations and used the Kappa Statistic (Agresti 1996) to test whether the road presented a boundary with respect to habitat use. The permeability of local rivers was not tested due to low sample size of feral swine utilizing habitat near a river. 


\section{RESULTS}

We collected and analyzed 4,625 locations ( $n=15$ individual feral swine) from South Texas Plains, 1,782 locations ( $n=11$ individual feral swine) from Post Oak Savanna, and 990 locations $(n=8$ individual feral swine) from Pineywoods (Table 2). In the South Texas Plains 38\% $(n=6)$ of domestic swine facilities were located in mesquite shrubland, $19 \%(n=3)$ in cropland, $19 \%$ in bare-ground, $13 \%(n=2)$ in mesquite-oak, and the remaining two were located in riparian woodland and grasslands. Facilities in the Post Oak Savanna had $47 \%(n=7)$ located in grassland, 27\% $(n=4)$ in cropland, 20\% $(n=3)$ in mesquite-oak woodlands, and one facility in live oak (Q. virginiana) woodlands. Fifty percent $(n=10)$ of domestic swine facilities in the Pineywoods were located in pine forest, 33\% $(n=6)$ in grasslands, and 10\% $(n=2)$ in riparian woodland.

We did not find a higher density of locations in the rightof-way polygons at any of the study sites $(t=-0.557$, $P>0.6)$. In the boundary analysis, we only found feral swine to cross paved, 2-lane roads in the Post Oak Savanna study site. There, out of 1,794 locations, we recorded 7 incidences where feral swine crossed a road, suggesting that paved, 2-lane roads presented a boundary to feral swine movement $(K=-0.21, P>0.43)$. There was no crossing of paved, 2-lane roads in the South Texas Plains or Pineywoods ( $n=4,396$ and $n=990$ locations). Additionally, many of the areas of utilization demonstrated the influence of a paved, 2-lane road, with the shape of the kernel generally following the road (Fig. 3). All 3 sites had multiple caliche dirt road crossing events $(K=0.17, P<0.001$ (Pineywoods ecotype); $K=0.14, P<0.02$ (Post Oak Savanna); $K=0.07$, $P<0.001$ (S Texas Plains). Additionally, both study sites in East Texas were adjacent to a river (average range of widths was $30-70 \mathrm{~m}$ ); however, the 2 feral swine that utilized habitat within $100 \mathrm{~m}$ did not cross their respective rivers.

Interactions did not occur among site, sex, and period $\left(F_{1,16} \leq 1.25, P \geq 0.27\right)$. Differences in kernel size did occur among sites $\left(F_{2,16}=6.38, P=0.005\right.$; Table 2$)$, with the Post Oak Savanna and Pineywood sites similar to each other, but each was different from the South Texas Plains ecotype. In the Post Oak Savanna and Pineywoods ecotypes the size of utilized areas did not differ $\left(F_{1,16}=0.84, P=0.37\right)$ between female and male feral swine, nor between wet and dry periods $\left(F_{1,16}=0.06\right.$, $P=0.81$ ). Similarly, in the South Texas Plains, we did not find differences among wet, normal, and dry periods $\left(F_{2,16}=0.51, P=0.60\right)$, and no interaction was found between sex and period $\left(F_{2,16}=0.60, P=0.56\right)$.

Feral swine did not use vegetation types proportional to availability in any of the 3 ecotypes, and demonstrated PDSI period variation in their use (Tables 1 and 3; Fig. 4). Of note, at South Texas Plains sites during the wet period, feral swine were more likely to occur on bare-ground $(\beta=0.71$, $\mathrm{SE}=0.19)$ while using remaining vegetation types at proportional or less than proportional levels. Feral swine were less likely to occur in urban, grassland, and mesquite-oak woodland vegetation types during the normal period $(\beta=-15.42, \quad \mathrm{SE}=312.5 ; \quad \beta=-1.9, \quad \mathrm{SE}=0.2 ; \beta=$ $-1.1, \mathrm{SE}=0.18$ ), but occurred in remaining vegetation types at proportional levels to availability. During the dry period, feral swine occurred in all vegetation types at proportional levels, not demonstrating preference or avoidance. At Post Oak Savanna sites, feral swine movements were more likely to occur in grassland vegetation types during the wet period ( $\beta=1.12, \mathrm{SE}=0.57)$, whereas occurrence was less likely in cropland and mixed oak woodlands $(\beta=-0.35, \quad \mathrm{SE}=0.13 ; \beta=-0.47, \quad \mathrm{SE}=0.15) . \quad$ All remaining vegetation types had feral swine occurrence at

Table 2. Study site, sex (F and M), location sample size, and utilized-area kernel calculations for collared feral swine in 3 Texas, USA, ecotypes, May 2004-July 2006.

\begin{tabular}{|c|c|c|c|c|c|c|c|c|}
\hline \multirow[b]{2}{*}{ Study area } & \multicolumn{4}{|c|}{ No. of locations } & \multicolumn{4}{|c|}{$\mathrm{Km}^{2}$ area of kernel } \\
\hline & Total & Wet & Normal & Dry & Total & Wet & Normal & Dry \\
\hline \multicolumn{9}{|c|}{ South Texas Plains $(n=15)$} \\
\hline $\bar{x}=$ & 308.33 & 223.8 & 169.63 & 206.0 & 18.67 & 14.06 & 22.23 & 19.5 \\
\hline $\mathrm{se}=$ & 83.36 & 52.05 & 21.29 & 35.77 & 3.94 & 2.67 & 4.42 & 1.5 \\
\hline $\bar{x}(n=5 \mathrm{~F})=$ & 553.4 & & & & 17.2 & & & \\
\hline $\mathrm{se}=$ & 209.54 & & & & 6.2 & & & \\
\hline $\bar{x}(n=10 \mathrm{M})=$ & 185.8 & & & & 19.4 & & & \\
\hline $\mathrm{se}=$ & 38.23 & & & & 5.3 & & & \\
\hline \multicolumn{9}{|c|}{ Post Oak Savanna $(n=11)$} \\
\hline $\bar{x}=$ & 162.27 & 63.91 & & 135.25 & 5.61 & 4.7 & & 6.0 \\
\hline se $=$ & 52.02 & 15.62 & & 45.47 & 0.89 & 0.93 & & 0.94 \\
\hline $\bar{x}(n=6 \mathrm{~F})=$ & 211.17 & & & & 4.6 & & & \\
\hline se $=$ & 87.66 & & & & 0.7 & & & \\
\hline $\bar{x}(n=5 \mathrm{M})=$ & 103.6 & & & & 7.7 & & & \\
\hline se $=$ & 42.17 & & & & 1.6 & & & \\
\hline \multicolumn{9}{|l|}{ Pineywoods $(n=8)$} \\
\hline $\bar{x}=$ & 123.75 & 99.13 & & 98.5 & 7.65 & 7.65 & & 4.5 \\
\hline se $=$ & 45.25 & 25.45 & & 36.25 & 1.83 & 1.85 & & 1.4 \\
\hline $\bar{x}(n=1 \mathrm{~F})=$ & 430 & & & & na & & & \\
\hline $\mathrm{se}=$ & na & & & & na & & & \\
\hline $\bar{x}(n=7 \mathrm{M})=$ & 80 & & & & 7.9 & & & \\
\hline se $=$ & 13.33 & & & & 2.1 & & & \\
\hline
\end{tabular}




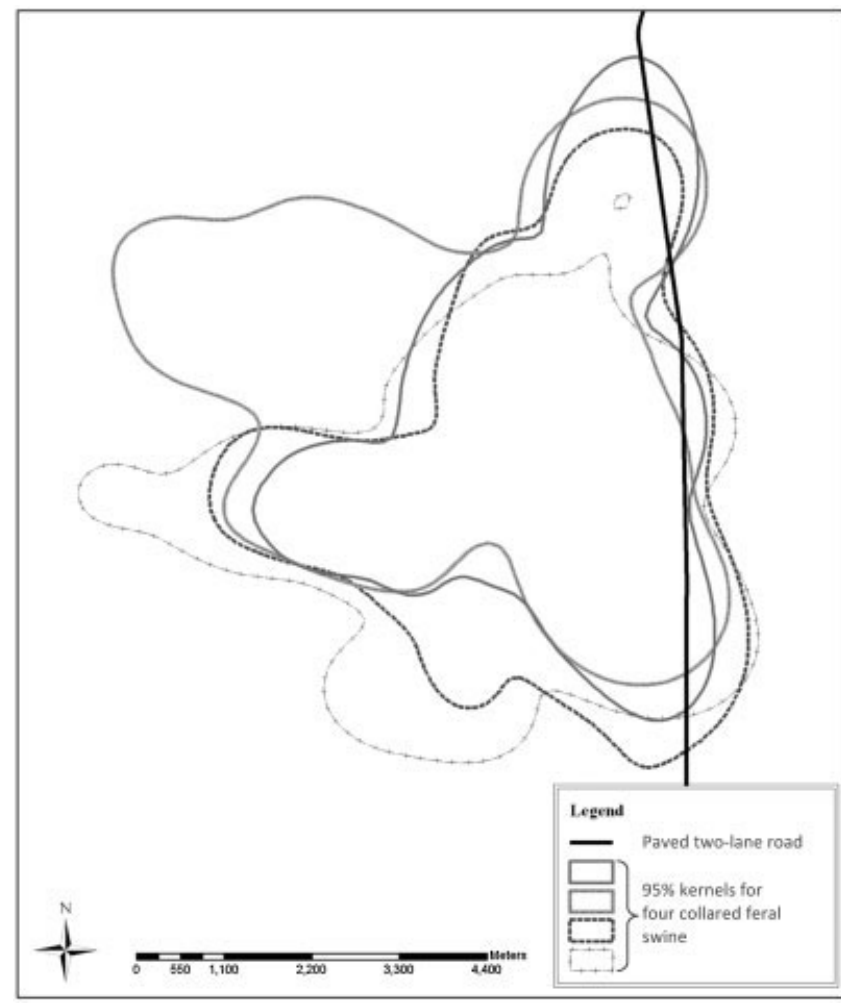

Figure 3. Example of paved, 2-lane road influence on shape of $95 \%$ kernel estimates. All locations, from each of the 4 feral swine shown, were only on west side of paved, 2-lane road, Texas, USA, May 2004-July 2006. proportional levels. The dry period at Post Oak Savanna sites showed feral swine occurring less in cropland and oak shrubland $(\beta=-0.95, \mathrm{SE}=0.18 ; \beta=-0.93, \mathrm{SE}=0.35)$, with proportional occurrence in the remaining vegetation types. At Pineywood sites, feral swine were more likely to occur in water oak (Q. nigra) woodlands vegetation $(\beta=0.57, \mathrm{SE}=0.29)$ and less likely to occur in cropland, riparian woodlands, and grasslands $(\beta=-13.38, \mathrm{SE}=$ $329.2 ; \beta=-0.84, \mathrm{SE}=0.32 ; \beta=-2.05, \mathrm{SE}=0.24)$. During the dry period at Pineywood sites, feral swine movements were more likely to occur in pine forest and water oak woodlands vegetation types $(\beta=38.29, \mathrm{SE}=1.02$; $\beta=16.69, \mathrm{SE}=1.12$ ), while the remaining vegetation types were used at proportional levels.

\section{DISCUSSION}

The risk, and cost, of feral-to-domestic disease transmission have been extensively outlined in the literature (Doster 1992, Witmer et al. 2003, Hutton et al. 2006); however, specific data regarding feral swine activities near domestic facilities remain limited (Wyckoff et al. 2009). We compared the dominant vegetation types surrounding the domestic swine facilities to those favored by our collared feral swine, and found that half of the small-scale facilities were surrounded by preferred vegetation types. In particular, our analysis showed nearly $50 \%$ of facilities in Post Oak Savanna ecotypes were surrounded by grasslands, which feral swine used

Table 3. Logistic regression models and their respective likelihood and goodness-of-fit tests, for habitats significantly used by feral swine in 3 ecotypes of Texas, USA, May 2004-July 2006.

\begin{tabular}{|c|c|c|c|c|c|c|c|c|c|c|c|c|}
\hline \multirow{3}{*}{$\begin{array}{l}\text { Ecotypes } \\
\text { PDSI period }^{\mathbf{a}}\end{array}$} & \multirow[b]{3}{*}{ Habitat type $\mathrm{b}^{\mathrm{b}}$} & \multirow[b]{3}{*}{$x^{2}$} & \multirow[b]{3}{*}{$P$} & \multicolumn{3}{|c|}{ Likelihood ratio $^{c}$} & \multicolumn{6}{|c|}{ Goodness-of-fit tests } \\
\hline & & & & \multirow[b]{2}{*}{$x^{2}$} & \multirow[b]{2}{*}{ df } & \multirow[b]{2}{*}{$P$} & \multicolumn{3}{|c|}{ Deviance $^{\mathrm{d}}$} & \multicolumn{3}{|c|}{ Pearson $^{\mathrm{e}}$} \\
\hline & & & & & & & $\chi^{2}$ & df & $P$ & $\chi^{2}$ & df & $P$ \\
\hline \multicolumn{13}{|c|}{ South Texas Plains } \\
\hline \multirow[t]{5}{*}{ Wet } & Bare Ground & 13.84 & $<0.001$ & 245.22 & 5 & $<0.001$ & 0.00 & 0 & & 0.00 & 0 & \\
\hline & Cropland & 22.63 & $<0.001$ & & & & & & & & & \\
\hline & Urban & 67.30 & $<0.001$ & & & & & & & & & \\
\hline & Grasslands & 83.07 & $<0.001$ & & & & & & & & & \\
\hline & Mesquite-oaks woodlands & 34.98 & $<0.001$ & & & & & & & & & \\
\hline \multirow[t]{3}{*}{ Normal } & Urban & 46.51 & $<0.001$ & 172.31 & 2 & $<0.001$ & 6.50 & 4 & 0.16 & 5.76 & 4 & 0.22 \\
\hline & Grasslands & 100.85 & $<0.001$ & & & & & & & & & \\
\hline & $\begin{array}{c}\text { Mesquite-oaks woodlands } \\
\mathrm{n} / \mathrm{a}\end{array}$ & 41.92 & $<0.001$ & & & & & & & & & \\
\hline \multicolumn{13}{|c|}{ Post Oak Savanna } \\
\hline \multirow[t]{3}{*}{ Wet } & Cropland & 8.58 & 0.003 & 20.11 & 3 & $<0.001$ & 4.80 & 4 & 0.31 & 4.82 & 4 & 0.31 \\
\hline & Grasslands & 4.26 & 0.039 & & & & & & & & & \\
\hline & Mixed oak woodlands & 6.94 & 0.008 & & & & & & & & & \\
\hline \multirow[t]{2}{*}{ Dry } & Cropland & 25.89 & $<0.001$ & 33.86 & 2 & $<0.001$ & 6.63 & 4 & 0.16 & 5.51 & 4 & 0.24 \\
\hline & Oak shrubland & 7.51 & 0.006 & & & & & & & & & \\
\hline \multicolumn{13}{|l|}{ Pineywoods } \\
\hline \multirow[t]{4}{*}{ Wet } & Cropland & 6.10 & 0.014 & 127.59 & 4 & $<0.001$ & 3.03 & 2 & 0.22 & 2.61 & 2 & 0.27 \\
\hline & Riparian woodlands & 7.41 & 0.007 & & & & & & & & & \\
\hline & Grasslands & 97.93 & $<0.001$ & & & & & & & & & \\
\hline & Water oak woodlands & 3.86 & 0.049 & & & & & & & & & \\
\hline \multirow[t]{2}{*}{ Dry } & Pine forest & 28.71 & $<0.001$ & 41.09 & 2 & $<0.001$ & 1.70 & 2 & 0.43 & 1.33 & 2 & 0.52 \\
\hline & Water oak woodlands & 9.60 & 0.002 & & & & & & & & & \\
\hline
\end{tabular}

${ }^{\text {a }}$ Palmer Drought Severity Index (PDSI)-delineated periods.

${ }^{\mathrm{b}}$ Habitat classification according to the Texas GAP Analysis Project, 2003.

${ }^{\mathrm{c}}$ Likelihood-ratio test.

${ }^{\mathrm{d}}$ Deviance goodness-of-fit test.

e Pearson's $\chi^{2}$ goodness-of-fit test. 

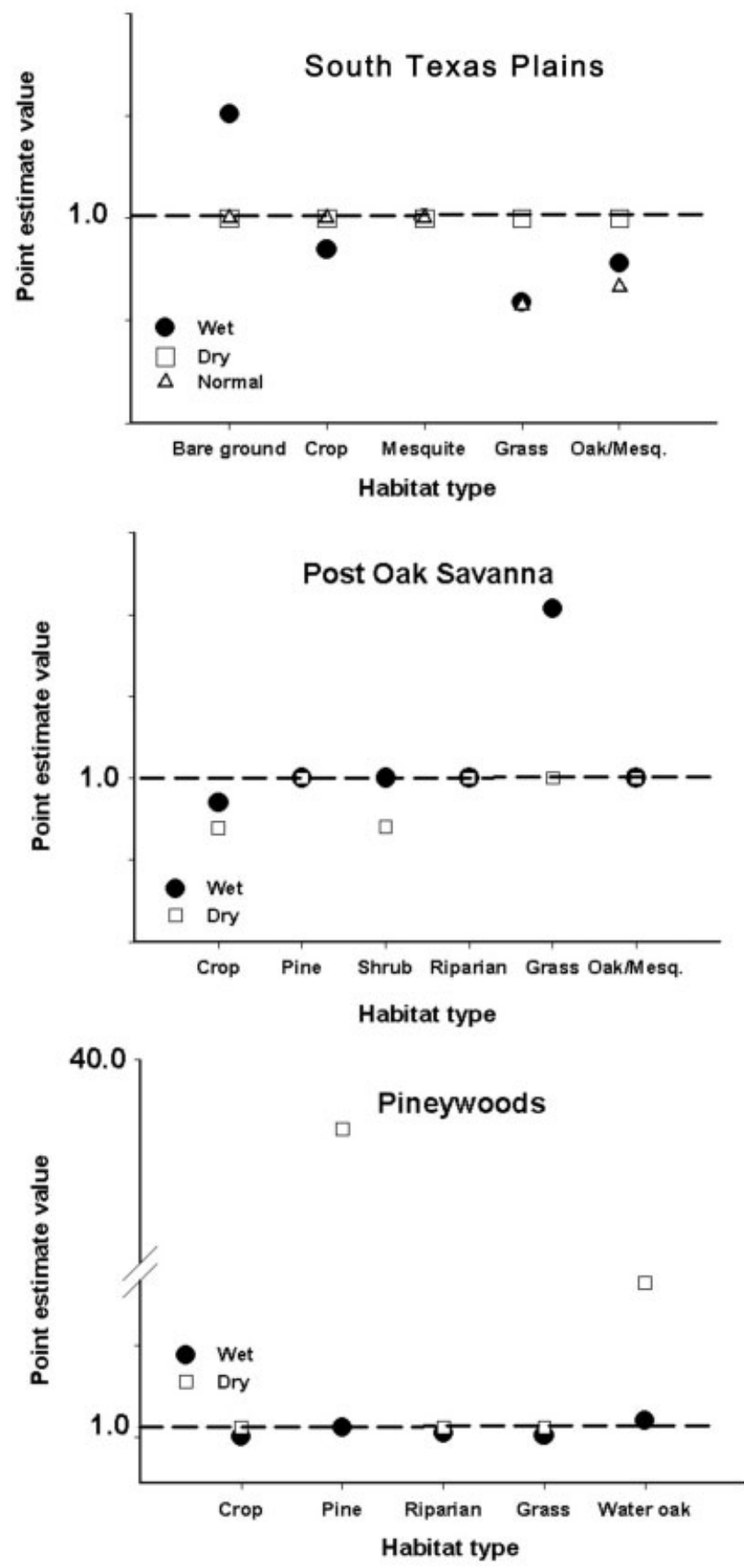

Figure 4. Feral swine habitat-use proportions with regard to availability scaled from $<1$ (demonstrating under use), 1 (proportional use), and $>1$ (showing an overuse compared to proportional availability). PDSI periods are represented as wet $(\bullet)$, dry $(\square)$, and normal $(\Delta)$ for each Texas, USA ecotype, May 2004-July 2006.

3 times more than expected during the wet period. Of the facilities in the Pineywoods ecotype, 50\% were located in pine forest, which during the dry period feral swine used 38 times more than expected. These similar habitat associations suggest feral swine may readily use, and be found in, vegetation where domestic swine facilities are located, thereby facilitating contact and possible disease transmission. Wyckoff et al. (2009) demonstrated that feral swine do have direct contact with domestic swine in small-scale facili- ties, supporting common anecdotal testaments from local farmers and ranchers (Feral Swine Subcommittee on Brucellosis and Pseudorabies 2005).

Pipeline and power line right-of-ways were not favored over the rest of the landscape and, thus, do not appear to be corridors for feral swine movement. Saunders and Kay (1991) suggested that with some exceptions, natural and manmade boundaries such as rivers or roads influence feral swine movement. We found that paved, 2-lane roads presented a boundary to feral swine movement, likely due to continual vehicular traffic on such roads. Caliche roads, however, did not impede feral swine movements, allowing the animals to use the landscape regardless of road presence. Auto traffic on caliche roads was substantially less than paved 2-lane roads, which may account for the unimpeded movement across these roads. The rarity of crossing events of paved, 2-lane roads, and the linear edge of the kernels neighboring paved, 2-lane roads suggest the landscape effect that these roads can have on feral swine movement. Feral swine-vehicle collisions, and the 7 crossing events we recorded in the Pineywoods ecotype, suggest that paved 2-lane roads are not impermeable to feral swine, but do influence feral swine habitat use.

Similar to previous research, our data suggest that spatial complexity of the habitat and availability of food, water, and shelter impact the size of areas used (Sanderson 1966; Singer et al. 1981; Dexter 1998, 1999; Mersinger and Silvy 2007). This was demonstrated by different sizes of areas utilized at our 3 sites. Kernel sizes in the South Texas Plains were significantly larger than Post Oak Savanna and Pineywoods, which could be explained by water availability as is commonly cited (Wood and Brenneman 1980, Ilse and Hellgren 1995, Caley 1997, Dexter 1998, Mersinger and Silvy 2007). Post Oak Savanna and Pineywoods have water throughout in the form of rivers, creeks, ponds, and seasonal swamps. South Texas Plains water and food sources were limited and more dispersed; thus, feral swine in South Texas Plains would have to utilize more area to have access to all necessary resources.

In general, other studies have found that feral swine have fidelity for seasonal ranges (Singer et al. 1981, Pech and McIlroy 1990), with winter-spring ranges being larger than summer-autumn ranges (Kurz and Marchinton 1972, Mersinger and Silvy 2007). Within an individual's home range, movements across the landscape are considered nomadic and motivated by food and thermoregulation (Saunders and Kay 1991, Sweeney et al. 2003). However, in our study, we did not find a difference in the size of area used among the wet, normal, or dry periods. This result was contrary to expectation because the dry period would likely have lower resource availability and, thus, feral swine would have to explore larger areas to find forage. However, it is possible that feral swine instead found a water source and did not leave the area for the dry period, resulting in no difference among periods. Alternatively, as may have been the case in East Texas, pressures during wet periods, such as hunting pressure or flooding, could result in feral swine moving around the landscape. The utilization of a large area provides opportunity for interaction with other feral swine, as well as 
possible interaction with domestic swine in small-scale swine operations as shown in Wyckoff et al. (2009).

The use of the TX-GAP classification data allowed for efficient analysis of large spatial studies across 3 Texas ecotypes. The TX-GAP data set was released in 2003; as such, the scientific literature is lacking in comparable habitat use analysis for feral swine. However, we believe the habitat use preferences reported here agree with previously mentioned habitat use studies. We found that during the wet period in the Post Oak Savanna ecotype, where wooded riparian swamp areas are prevalent, feral swine began utilizing grasslands that would be less likely to flood and possibly filled with new vegetation growth and soil invertebrates (Fig. 4). This preference occurred while they underutilized mixed oak woodlands, which were generally along riparian and seasonally flooded areas. A similar flood-dependent use of habitats was found in the Pineywood ecotype. In both PDSI periods, feral swine used water oak forest above proportional availability. However, in the wet period when much of the habitat was under water, use of the water oak forest vegetation was only slightly higher than proportion, while in the dry period use greatly increased. It is likely that this bottomland habitat provided water, shade, and forage even in the dry period. This is supported by observations of local hunters who observe that animals move to swamps and bottomlands during the summer months, which correlated with the dry period. The large increase in pine forest vegetation use is potentially a result of loblolly pines releasing their seeds during the autumn, which in 2005 was during the dry period. Feral swine were likely spending time in water oak forest bottomlands for shelter and pine forests for food.

In the South Texas Plains the lack of difference between size of utilized areas during wet and dry periods could be due to the propensity to use supplemental feed along the roads on private property during hunting season. Though the feed is provided as an attractant for white-tailed deer (Odocoileus virginianus), feral swine opportunistically feed as well, and thus are encouraged to remain in the area. This is supported by the increased use of bare-ground by feral swine during the wet period, in which many locations were collected during the deer-hunting season (Nov-Jan). After hunting season, sorghum crops became available and feral swine utilized cropland at proportional levels during the dry period while underutilizing them during the wet period, potentially because of the supplemental feed; however, our analysis did not include specifics about crop cycles. Contrary to expectation in the South Texas Plains sites, feral swine did not increase their use of riparian woodlands during the dry period; however, this was a rare vegetation type in these sites.

\section{MANAGEMENT IMPLICATIONS}

An understanding of habitat use and preferences, as well as the range over which feral swine travel, is essential in the effective management of feral swine for disease transmission prevention and disease eradication efforts. Knowledge of habitat preferences from this study can aid in more efficient application of targeted management techniques such as trapping or hunting. Our results suggest boundaries such as roads could be used as tools for management. For example, locations near high-traffic roads or large rivers could be used as maintenance zones, where feral swine populations are depopulated, allowing the boundary to discourage future repopulation. However, this method may only be effective in certain environments and should be more thoroughly tested. In addition to using targeted management around boundaries, Caley (1997) suggested a depopulation buffer zone to manage feral swine problems around areas of concern. The creation of a buffer (either vegetation-based or depopulation-based, radius $=$ average kernel $\mathrm{km}^{2}$ ) targeting preferred habitat around domestic swine facilities would effectively reduce the feral population of concern, with moderate maintenance required for individuals that immigrate into the area.

\section{ACKNOWLEDGMENTS}

We thank the U.S. Department of Agriculture, Animal Plant Health Inspection Services, Veterinary Services and Wildlife Services, National Wildlife Research Center and the Caesar Kleberg Wildlife Research Institute for financial support. Land access and logistical support was generously provided by Texas Parks and Wildlife Department, Texas A\&M University, Texas A\&M University-Kingsville, Temple Inland Company, King Ranch, Inc., D. Baldree, M. Benton, R. Brookshire, B. Colston, Jr., B. Colston, III, F. C. Flournoy, J. Maxy, K. West, and private landowners. We would also like to thank T. Atwood, S. Edwards, J. Fischer, M. Hall, B. Hopkins, D. Krapes, M. Lavelle, D. Long, J. Moczygemba, K. Porter, E. Redeker, M. Reidy, L. Roberson, M. Schenk, H. Smith, J. Stevenson, J. Treadway, S. Ynostrosa, D. Walters, E. Wehland, A. Windham, and S. Wyckoff for assistance in fieldwork, editing, and other project aspects. This is publication number 08-124 of the Caesar Kleberg Wildlife Research Institute.

\section{LITERATURE CITED}

Adkins, R. N., and L. A. Harveson. 2007. Demographics and spatial characteristics of feral hogs in the Chihuahuan Desert, Texas. HumanWildlife Conflicts 1:152-160.

Agresti, A. 1996. Introduction to categorical data analysis. John Wiley and Sons, New York, New York, USA.

Atwood, T. A., K. C. VerCauteren, T. J. DeLiberto, H. J. Smith, J. S. Stevenson, and B. V. Thomsen. 2007. Coyotes as sentinels for monitoring bovine tuberculosis prevalence in white-tailed deer. Journal of Wildlife Management 71:1545-1554.

Auld, B. A., and C. A. Tisdell. 1986. Impact assessment of biological invasions. Pages 79-88 in R. H. Groves and J. J. Burdon, editors. Ecology and biological invasions: an Australian perspective. Cambridge University Press, Cambridge, England.

Bailey, J. A. 1984. Principles of wildlife management. John Wiley and Sons, New York, New York, USA.

Boyce, M. S., P. R. Vernier, S. E. Nielsen, and F. K. A. Schmiegelow. 2002. Evaluating resource selection function. Ecological Modeling 157:281300.

Caley, P. 1997. Movements, activity patterns and habitat use of feral pigs (Sus scrofa) in a tropical habitat. Wildlife Research 24:77-87.

Delgado-Acevedo, J. H. 2010. Feral pig management in South Texas a landscape genetics approach. Thesis, Texas A\&M University, Kingsville, USA.

Dexter, N. 1998. The influence of pasture distribution and temperature on habitat selection by feral pigs in a semi-arid environment. Wildlife Research 25:547-559. 
Dexter, N. 1999. The influence of pasture distribution, temperature and sex on home-range size of feral pigs in a semi-arid environment. Wildlife Research 26:755-762.

Doster, G. L., editor. 1992. Wild swine disease awareness. Southeastern Cooperative Wildlife Disease Study Briefs 8:3-4.

Feral Swine Subcommittee on Brucellosis and Pseudorabies. 2005. Feral swine subcommittee on brucellosis and pseudorabies report. U.S. Animal Health Association, St. Joseph, Missouri, USA.

Fogarty, E. P. 2007. National distribution of and stakeholder attitudes toward feral hogs. Thesis, Mississippi State University, Mississippi State, USA.

Forman, R. T. T. 1995. Land mosaics: the ecology of landscapes and regions. Cambridge University Press, Cambridge, England.

Gipson, P. S., B. Hlavachick, and T. Bereger. 1998. Range expansion by wild hogs across the central United States. Wildlife Society Bulletin 26:279-286.

Gould, F. W. 1975. Texas plants: a checklist and ecological summary. Texas Agricultural Experimental Station, College Station, USA.

Hall, L. S., P. R. Krausman, and M. L. Morrison. 1997. The habitat concept and a plea for standard terminology. Wildlife Society Bulletin 26:173-182.

Hayes, R., S. Riffell, R. Minnis, and B. Holder. 2009. Survival and habitat use of feral hogs in Mississippi. Southeastern Naturalist 8:411-426.

Hutton, T., T. DeLiberto, S. Owen, and B. Morrison. 2006. Disease risks associated with increasing feral swine numbers and distribution in the United States. Wildlife and Fish Health Committee report. Midwest Association of Fish and Wildlife Agencies.

Ilse, L. M., and E. C. Hellgren. 1995. Resource partitioning in sympatric populations of collared peccaries and feral hogs in South Texas. Journal of Mammalogy 76:784-799.

Jay, M. T., M. Cooley, D. Carychao, G. W. Wiscomb, R. A. Sweitzer, L. Crawford-Miksza, J. A. Farrar, D. K. Lau, J. O'Connell, A. Millington, R. V. Asmundson, E. R. Atwill, and R. E. Mandrell. 2007. Escherichia coli O157:H7 in feral swine near spinach fields and cattle, Central California coast. Emerging Infectious Diseases 13:1908-1911.

Kenward, R. E. 2001. A manual for wildlife radio tagging. First edition. Academic Press, San Diego, California, USA.

Kurz, J. C., and R. L. Marchinton. 1972. Radiotelemetry studies of feral hogs in South Carolina. Journal of Wildlife Management 36:1240-1248.

Littell, R. C., G. A. Milliken, W. W. Stroup, R. D. Wolfinger, and O. Schabenberber. 2006. SAS for mixed models. Second edition. SAS Institute, Cary, North Carolina, USA.

Manly, B. F. J., L. L. McDonald, D. L. Thomas, T. L. McDonald, and W. P. Erickson. 2002. Resource selection by animals: statistical design and analysis for field studies. Kluwer Academic, Norwell, Massachusetts, USA.

Massei, G., P. V. Genov, B. W. Staines, and M. L. Gorman. 1997. Factors influencing home range and activity of wild boar (Sus scrofa) in a Mediterranean coastal area. Journal of Zoology London 242:411-423.

Mersinger, R. C., and N. J. Silvy. 2007. Range size, habitat use, and dial activity of feral hogs on reclaimed surface-mined lands in East Texas. Human-Wildlife Conflicts 1:161-167.

Mladenoff, D. J., T. A. Sickley, R. G. Haight, and A. P. Wydeven. 1995. A regional landscape analysis and prediction of favorable gray wolf habitat in the Northern Great Lakes Region. Conservation Biology 9:279294.

Moen, R., C. L. Burdett, and G. J. Niemi. 2008. Movement and habitat use of Canada lynx during denning in Minnesota. The Journal of Wildlife Management 72:1507-1513.
National Oceanic Atmospheric Administration [NOAA]. 2006. National Weather Service Climate Prediction Center, Drought Severity Index by Division. < http://www.cpc.noaa.gov/products/analysis_monitoring/ regional_monitoring/palmer/>. Accessed 1 Nov 2006.

Palmer, W. C. 1965. Meteorological drought. Research paper 45. U.S. Department of Commerce Weather Bureau, Washington, D.C., USA.

Pech, R. P., and J. C. McIlroy. 1990. A model of the velocity of advance of foot and mouth disease in feral pigs. Journal of Applied Ecology 27:635650.

Rodgers, A. R., and A. P. Carr. 1998. Home range tools for ArcGIS. $<$ http://blue.lakeheadu.ca/hre/>. Accessed 1 Jul 2005.

Sanderson, G. 1966. The study of mammal movements: a review. Journal of Wildlife Management 30:215-235.

Saunders, G., and H. Bryant. 1988. The evaluation of a feral pig eradication program during a simulated exotic disease outbreak. Wildlife Research 15:73-81.

Saunders, G., and B. Kay. 1991. Movements of feral pigs at Sunny Corner, New South Wales. Wildlife Research 18:49-61.

Southeastern Cooperative Wildlife Disease Study [SCWDS]. 2008. National Feral Swine Mapping System. <http://www.feralswinemap. org $>$. Accessed $10 \mathrm{Feb} 2008$.

Singer, F. J., D. K. Otto, A. R. Tipton, and C. P. Hable. 1981. Home ranges, movements, and habitat use of European wild boar in Tennessee. Journal of Wildlife Management 45:343-353.

Sweeney, J. R., J. M. Sweeney, and S. W. Sweeney. 2003. Feral hogs. Pages 1164-1179 in G. A. Feldhamer, B. C. Thompson, and J. A. Chapman, editors. Wild mammals of North America: biology, management, and conservation. Second edition. The Johns Hopkins University Press, Baltimore, Maryland, USA.

Synatzske, D. R. 1979. Status of the feral hog in Texas. Unpublished Report, Texas Parks and Wildlife Department, Austin. 9 pp.

Taylor, R. B. 1993. History and distribution of feral hogs in Texas. Pages 17-21 in C. W. Hanelka and J. F. Cadenheads, editors. Feral swine: a compendium for resource managers. Texas Agricultural Extension Service, Kerrville, USA

Taylor, R. B., E. C. Hellgren, T. M. Gabor, and L. M. Ilse. 1998. Reproduction of feral pigs in South Texas. Journal of Mammalogy 79:1325-1331.

U.S. Geological Survey GAP Analysis Project. 2003. Texas GAP analysis project: final report. $<\mathrm{http} / /$ www.nbii.gov/portal/community/GAP Analysis_Program/Communities/Maps,_Data,_\&_Reports/>. Accessed 1 Apr 2006.

Witmer, G. W., R. B. Sanders, and A. C. Taft. 2003. Feral swine-are they a disease threat to livestock in the United States? Proceedings of the Wildlife Damage Management Conference 10:316-325.

Wood, G. W., and R. E. Brenneman. 1980. Feral hog movements and habitat use in coastal South Carolina. Journal of Wildlife Management 44:420-427.

Wyckoff, A. C., S. E. Henke, T. A. Campbell, D. G. Hewitt, and K. C. VerCauteren. 2007. GPS telemetry collars: considerations before you open your wallet. Proceedings of the Wildlife Damage Management Conference 12 (Addendum): 571-576.

Wyckoff, A. C., S. E. Henke, T. A. Campbell, D. G. Hewitt, and K. C. VerCauteren. 2009. Feral swine contact with domestic swine: a serologic survey and assessment of potential for disease transmission. Journal of Wildlife Diseases 45:422-429.

Associate Editor: Breck. 